\title{
Modeling Nutrient Regeneration in the Ocean with an Aquarium System
}

\author{
Jonathan H. Sharp, Andrew C. Frake, Graham B. Hillier* and Peter A. Underhill \\ College of Marine Studies, University of Delaware, Lewes, Delaware 19958, USA
}

\begin{abstract}
Dynamic processes in a recirculating seawater aquarium system have been studied in an attempt to assess nutrient regeneration. Sufficient monitoring has been done over time to construct elemental budgets. Results in nutrient and organic chemistry of this system are compared to published bottle experiments, bell jar experiments, and open system modeling. In regard to chemical species and regeneration rates, the aquarium system is a better model than bottle or bell jar experiments for assessing natural mixed water-column phenomena. An aquarium provides a useful experimental tool: regeneration can be measured and the otherwise unquantifiable organic source can be back calculated. Such a system can give realistic regeneration rates, provide information on chemical species produced, and serve for exploring geochemical behavior. Data on elemental budgets on incoming water and the regeneration products indicate that the dissolved organic phosphorus pool is small and rather labile when compared to the dissolved organic nitrogen pool. From this study and analysis of published coastal water works, it appears that a relatively consistent 54 to $62 \%$ of the total nitrogen (excluding gases) are in the dissolved organic pool.
\end{abstract}

\section{INTRODUCTION}

Microbial nutrient regeneration is a major rate-controlling process for the biological productivity of the oceans. Yet it is almost impossible to measure regeneration directly in marine environments. The plant-limiting nutrients are cycled from inorganic forms to organic forms via primary producers, through food chains, and eventually back to inorganic forms through bacterial decomposers. Appreciable recycling of nutrients also takes place through grazer excretion (but that is not the subject of this paper). The general picture of organic $\mathrm{C}, \mathrm{N}$, and $\mathrm{P}$ cycling is known and an average proportional relationship of elements has been documented (Redfield et al., 1963). This stoichiometric relationship is based upon an average elemental composition for plankton with C:N:P of 106:16:1 by atom ('Redfield ratio'), and an average oceanic seawater content for nitrate to phosphate of 16:1. The relationship is often summarized to show the formation and breakdown of organic matter with a

\footnotetext{
- Current address: Northlands, St. Georges 1-05, Bermuda
}

balanced stoichiometry for $\mathrm{C}, \mathrm{N}, \mathrm{P}, \mathrm{H}$, and $\mathrm{O}$ and referred to as 'Richards equation'.

Attempts to simulate natural nutrient regeneration in closed vessels of seawater (Cooper, 1935; von Brand et al., 1937, 1939, 1940, 1941, 1942; Hoffman, 1956; Gotterman, 1964; Grill and Richards, 1964; Adams, 1974) have yielded some valuable information, but many details are still not known and extrapolation from closed vessels to the natural environment is not very successful. Important field data on nutrient regeneration have been obtained from isolated anoxic environments (Richards, 1965; Atkinson and Richards, 1967; Richards et al, 1971; Cline and Richards, 1972). Comparable information has not become available from more open aerobic environments.

In trying to understand organic degradation and nutrient replenishment in the ocean, one is hindered by changing physical, chemical, and biological conditions. One approach is to enclose physically or conceptually (modeling) a large parcel of seawater, and to look at reactions within and potential exchange with surrounding waters. Closed experimental systems have been used for some studies but not with thorough elemental budgets (Menzel, 1977; Pilson, 1979). The Lagrangian method of following a parcel of water and 
measuring changes within it (e.g. Barber et al., 1971; Weibe et al., 1976) shows promise, but has not been done often nor with very extensive measurements.

Another approach to understanding nutrient regeneration has been to enclose a small portion of water over the sea bottom and look at short-term changes within (Rowe et al., 1975; Nixon et al., 1976a; Kaplan et al., 1979; McCaffrey et al., 1980). This 'bell jar' approach, while informative, has serious limitations, including the partial or total omission of water-column processes, spatial and temporal heterogeneity in sampling, and confinement effects. Also, 'bell jar experiments essentially give fluxes which must then be interpreted for their dispersion within the overlying waters. Recent field attempts have been made at indirect rate determinations with isotope tags and conceptual models. These include ${ }^{15} \mathrm{NO}_{3}{ }^{-}$uptake as being indicative of microbial regeneration rates (Eppley et al., 1979; King and Devol, 1979) and ${ }^{15} \mathrm{NH}_{4}{ }^{+}$isotope dilution assays (Harrison, 1978). These are informative, although somewhat indirect and they also depend upon incubating samples.

We have attempted to estimate nutrient regeneration rates directly in the field without any bottle-incubation experiments, thus integrating over mesoscale space and time. This was done by monitoring chemical changes in coastal bottom waters over months (Sharp and Church, 1981; Sharp, 1982).

Monitoring of chemical changes over time in a recirculating seawater system is the subject of the present article. It is our contention that the same biochemistry (i.e. the Redfield model) should apply, perhaps with some qualifications, to all of the systems mentioned above and to the seawater system. Often with the Redfield model, the lack of fit is explained by evoking unmeasured forms of elements or by claims that the model should not fit (e.g. Nixon et al., 1976b; Webb and D'Elia, 1980). For this reason, it is important to try to measure all forms of the elements. In the present study, particulate and dissolved organic carbon, nitrogen, and phosphorus were measured, as well as inorganic nitrogen and phosphorus forms.

\section{MATERIALS AND METHODS}

The seawater system for this study (in the Cannon Laboratory of the University of Delaware in Lewes) is a dual system with one 9,500 l capacity fiberglass tank, the contents of which are static (stored), and two similar 9,500 l tanks linked together with contents constantly recirculating. The stored tank is filled periodically with coastal seawater (pumped at high tide from Indian River Inlet, Delaware). The two-tank recirculating system is linked to aquarium trays and fiberglass

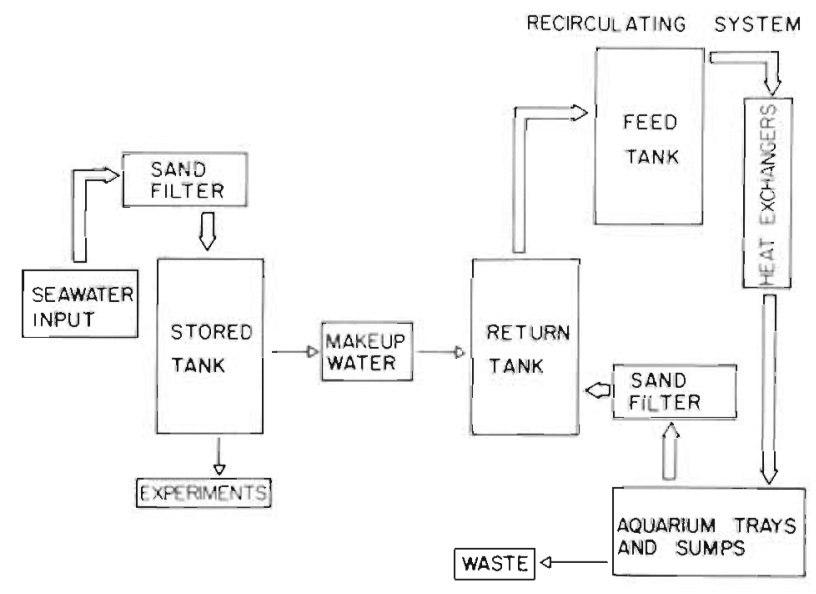

Fig. 1. Stored seawater tank and recirculating seawater system. Fresh seawater is put into stored tank which provides make-up water to recirculating system. In the recirculating system, water flows from feed tank through heat exchangers to aquarium trays and sumps, and back through sand filter to return tank. The sand filter used for initial seawater input to stored tank serves for gross particle reduction, but does not leave the water particle-free

return water sumps with sand filters and glass heat exchangers (Fig. 1). The aquarium trays are fiberglass or fiberglass-coated wood and all connecting pipes are polyvinyl chloride; an attempt was made to construct the system 'metal-free' and of inert materials.

The aquarium trays are open to ambient light from ceiling fluorescent lighting. The average illumination directly above the trays is about $3 \times 10^{15}$ quanta $\mathrm{cm}^{-2} \mathrm{~s}^{-1}$ as measured with a Biospherical Instrument QSL-100 Irradiance Meter.

The circulating time of the system was estimated from pumping rates and pumping frequencies of the sumps; it is equivalent to filtering the entire system through the filters slightly less than 4 times a day. The sand filters have $0.45 \mathrm{~mm}$ and $0.30 \mathrm{~mm}$ mesh quartz sand in series. Some water is lost regularly (by removal) from the recirculating tanks. This is made up periodically by transfer from the stored tank which regularly has some removal for experiments. New water is added to the stored tank, and water is transferred to the recirculating system at the time of these additions (on several-day intervals).

A study was made in 1978, in the winter (25 samples, January 7 to April 29) and in the summer (20 samples, June 15 to August 21). Water temperatures in the aquarium system were the same as room temperature (ca. $20^{\circ} \mathrm{C}$ ) for both periods. Thus, the microbial metabolism should have been similar on the 2 occasions although ambient winter populations may have been growing at temperatures above their normal ones. In each case, the system was flushed and filled with fresh seawater just prior to monitoring. Samples 
were drawn periodically for analyses from the two systems independent of the water additions and transfers.

Salinity was analyzed using an inductive salinometer. Particulate organic carbon and nitrogen were determined by elemental analyzer (Sharp, 1974). Particulate phosphorus was measured by a high temperature combustion method (Solorzano and Sharp, 1980a). The above particulate analyses were done on material retained on Whatman $\mathrm{GF} / \mathrm{C}$ filters, the filtrates of which were used for all the dissolved-matter analyses. Nitrate, nitrite, and phosphate were analyzed by standard methods (Strickland and Parsons, 1972) adjusted to $10 \mathrm{ml}$ aliquots. Ammonium was determined by the Solorzano (1969) method, modified by using the oxidizing solution of Liddicoat et al. (1975) and with $1 \mathrm{~h}$ color development in the dark at $35^{\circ} \mathrm{C}$. Dissolved organic carbon was analyzed by the persulfate oxidation method (Menzel and Vacarro, 1964) with modified sample preparation (Sharp, 1973). Dissolved organic nitrogen was determined by a modified version (Solorzano and Sharp, 1980b) of the persulfate oxidation method (Koroleff, 1976). Dissolved organic phosphorus was measured by a high-temperature combustion method (Solorzano and Sharp, 1980a).

\section{RESULTS OBTAINED IN THE SEAWATER SYSTEM}

The water budget of the system was derived from the water addition/transfer log. By averaging between mean input of new water and full capacity, the average volume of water in the stored tank was estimated as $6,800 \mathrm{l}$ in winter and 6,400 l in summer. In winter and summer, $62 \%$ of the water put into the stored tank was transferred to the recirculating system; the remainder was used directly for other experiments. The 19,000 l recirculating system was always full; residence times were estimated in winter as $37 \mathrm{~d}\left(5.7 \times 10^{4} \mathrm{l}\right.$ added over $111 \mathrm{~d})$ and in summer as $20 \mathrm{~d}\left(6.4 \times 10^{4} \mathrm{l}\right.$ added over $68 \mathrm{~d}$ )

The stored tank showed slight increases with time in nitrate $\left(\mathrm{NO}_{3}{ }^{-}\right)$and phosphate $\left(\mathrm{PO}_{4}{ }^{-3}\right)$ when monitored between additions (Fig. 2) but little variation in most other parameters. Expected slight decreases in particulate matter and increases in salinity were seen. Calculations of decreases in particulate organic carbon concentration over time in the stored tank can be used for estimates of settling rates of particulate matter. Decreases during 3 to 5 -d intervals were calculated 7 times during the 2 monitoring periods. Starting carbon concentrations ranged from 107-561 $\mathrm{ggC}^{-1}$ and daily decay rates divided by starting concentrations gave percentage removal per day; values ranged from
$14.4 \%$ to $25.9 \%$ with an average of $18 \%$. The salinity in the stored tank, monitored only in summer, showed very slight changes, but it always increased when sampled between inputs (due to evaporation). The average salinity increase (from 8 intervals) was $0.016 \% \mathrm{~S} \mathrm{~d}^{-1}$; this is equivalent to an evaporative loss of $100 \mathrm{ml} \mathrm{d}^{-1}$. These 2 calculations show the predictability of processes in the stored tank.

The recirculating system revealed little variation in most parameters during the 2 study periods (see below), except for large increases in nitrate and phosphate over time (Fig. 2). These obviously come from oxidation of organic matter from the animals themselves and from food for the animals in the aquarium trays. Lack of increases in dissolved organic carbon, nitrogen and phosphorus, and lack of buildup of ammonium and nitrite, indicate that the recirculating system efficiently oxidizes the large organic inputs. Two minor exceptions to the generally constant level of dissolved parameters occurred in the intervals between 28 January - 3 February and 3-14 August. During these intervals maximum values for dissolved organic carbon (5.52 $\left.\mathrm{mg} \mathrm{Cl}^{-1}\right)$, ammonium $(9.94 \mu$ moles $\left.\mathrm{Nl}^{-1}\right)$, and nitrite $\left(1.55 \mu\right.$ moles $\left.\mathrm{Nl}^{-1}\right)$ were higher than at all other times, indicating heavier biological loading of the system. Table 1 gives the average values and ranges for both systems. The very low levels of particulate organic carbon, nitrogen, and phosphorus in the recirculating system indicate that the rapid filtration rate ( 4 times $\mathrm{d}^{-1}$ ) does not permit a significant phytoplankton population buildup in the water. Spot checks on chlorophyll a show values below $0.5 \mu \mathrm{g}^{-1}$. The extremely high nitrate and phosphate levels could otherwise support a very large phytoplankton population.

The average atomic ratio for particulate matter from the stored system was 113:15:1 which is a good fit to the model (the Redfield ratio of $C: N: P$ is $106: 16: 1$ ). The concentration of particulate matter from the recirculating system was considerably lower than that from the stored system, but the average ratio of $98: 14: 1$ is insufficiently different from the Redfield ratio.

The ratio of the average total inorganic nitrogen (nitrate, nitrite, plus ammonium) to phosphate in the stored tank during the summer period was $17: 1$. During the beginning of the winter period, the ratio was higher. The lack of data for dissolved organic nitrogen and phosphorus for the winter period does not permit dismissing the possibility of excess organic phosphorus. The ratio of total inorganic nitrogen to phosphate in the recirculating system was always greater than 16:1 and showed progressive increases between water transfers to the system. Since ammonium and nitrite were very low, nitrogen changes in the recirculating system are plotted for nitrate alone. 

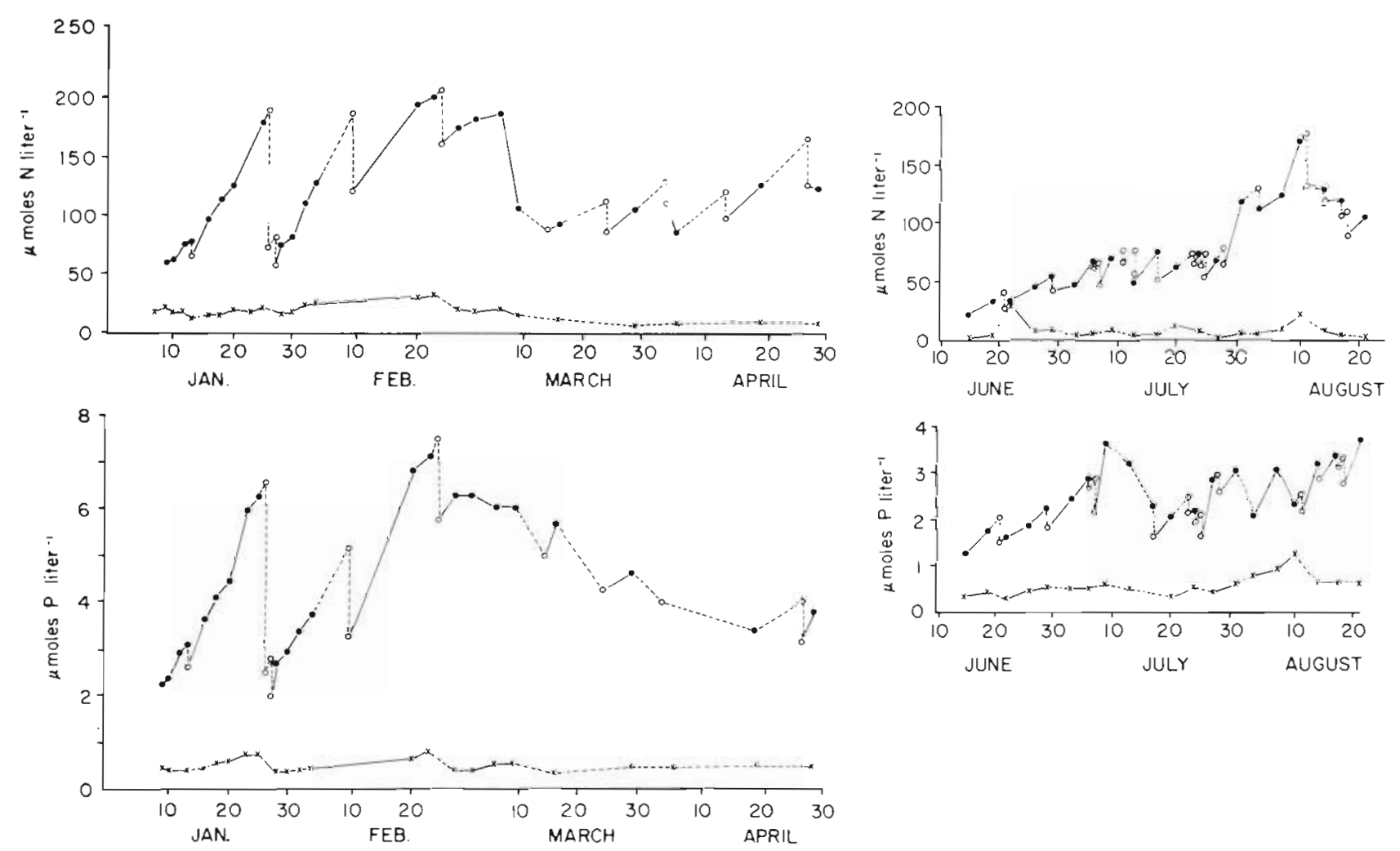

Fig. 2. Records of nitrate and phosphate in stored and recirculating seawater systems. Nitrate for winter period: upper left; phosphate for winter: lower left. Nitrate for summer; upper right; phosphate for summer: lower right. Stored system values ( $\times$ ) shown along the bottom and connected with solid lines for monitoring between inputs; dashed lines: new water additions since previous sample. Values measured in recirculating system $(\bullet)$ are supplemented by calculated values $(0)$ from extrapolation of production rate to the date of new water input and from dilution by the proportion of stored water put in on the date of water transfer; dashed lines: extrapolations and dilutions

Table 1. Average values and ranges for chemical parameters measured in stored and recirculating seawater systems in a winter (January-April) and summer (June-August) period. Ranges given in parentheses after averages. Values for dissolved constitutents omitted from recirculating system records at 28 January-3 February and 3-14 August due to apparently heavier biological loading during those intervals. High particulate values in the recirculating system input of new water on 22 June and 14 and 21 August are also omitted from averages. - parameter not measured

\begin{tabular}{|c|c|c|c|c|c|c|}
\hline \multirow[b]{2}{*}{ Parameter } & \multicolumn{2}{|c|}{ Winter } & \multicolumn{4}{|c|}{ Summer } \\
\hline & Stored & Recirculating & & Stored & & circulating \\
\hline Salinity $(\%)$ & - & - & 29.81 & $(28.93-30.16)$ & 29.75 & $(29.02-30.09)$ \\
\hline $\mathrm{NO}_{3}{ }^{-}\left(\mu\right.$ moles $\left.1^{-1}\right)$ & $17.8(7.82-32.4)$ & $125(60.5-201)$ & 7.63 & $(0.63-30.0)$ & 65.4 & $(21.0-118)$ \\
\hline $\mathrm{NO}_{2}^{-}\left(\mu \mathrm{l}^{-1}\right)$ & $0.22(0.13-0.38)$ & $0.31(0.17-0.62)$ & 0.02 & $(0.01-0.04)$ & 0.03 & $(0.01-0.05)$ \\
\hline $\mathrm{NH}_{4}{ }^{+}\left(\mu\right.$ moles $\left.\mathrm{l}^{-1}\right)$ & $0.93(0.48-2.03)$ & $0.09(<0.1-0.46)$ & 2.56 & $(<0.1-5.81)$ & 0.37 & $(<0.1-1.33)$ \\
\hline DON $\left.(\mu \text { moles }]^{-1}\right)$ & - & - & 17.7 & $(9.01-29.3)$ & 29.3 & $(13.2-43.4)$ \\
\hline $\mathrm{PO}_{4}{ }^{-3}\left(\mu\right.$ moles $\left.\mathrm{I}^{-1}\right)$ & $0.50(0.32-0.78)$ & $4.81(2.24-7.21)$ & 0.60 & $(0.33-1.24)$ & 2.52 & $(1.28-3.69)$ \\
\hline $\mathrm{DOP}\left(\mu\right.$ moles $\left.\mathrm{I}^{-1}\right)$ & - & - & 0.28 & $(0.16-0.42)$ & 0.23 & $(0.08-0.54)$ \\
\hline $\mathrm{DOC}\left(\mathrm{mg} \mathrm{Cl}^{-1}\right)$ & $1.37(1.22-1.77)$ & $1.52(1.32-1.79)$ & 1.63 & $(1.32-2.10)$ & 1.56 & $(1.08-1.75)$ \\
\hline Part $C\left(\mu g \mathrm{Cl}^{-1}\right)$ & $165(40-496)$ & $24 \quad(8-93)$ & 142 & $(27-561)$ & 69 & $(27-158)$ \\
\hline Part $N\left(\mu \mathrm{g} \mathrm{N} \mathrm{l^{-1 } )}\right.$ & - & - & 22 & $(4-91)$ & 10 & $(4-34)$ \\
\hline Part $P\left(\mu \mathrm{g} P \mathrm{l}^{-1}\right)$ & - & - & 39 & $(1.0-10.2)$ & 2.2 & $(.5-6.5)$ \\
\hline
\end{tabular}

The curves in Fig. 2 of nitrate and phosphate concentrations over time are constructed from measured data plus estimates by extrapolation of previous build- up rates and dilution by water transferred from the stored system (with lower nutrient content). The extrapolated portions of the curves fit well since the 
calculated dilution values generally fall in line with the subsequent measured ones. By taking regions of the curves with clear nutrient production, maximum rates are found with an average inorganic N:P production of 26 to 28 , clearly higher than the Redfield ratio of 16:1. Since the summer input and particulate matter showed the Redfield ratio, the values from the recirculating system indicate either a selective phosphate loss or nitrogen excess. The nutrient input must come entirely from oxidation of organic matter in the aquarium trays.

The phosphate loss could have occurred if phosphate minerals were precipitated within the system, probably in the sand filters. Phosphates in sediments are often divided into 3 major classes: calcium, iron and aluminum, and organic (Morse and Cook, 1978). Organic phosphorus buildup in the filters is an unlikely explanation, because it should not provide a phosphate loss preferential to nitrogen. Apatite or mixed carbonate-apatites are possible calcium precipitates that could form in the quartz sand filters (Stumm and Morgan, 1970; Atlas and Pytkowicz, 1977). Ferrous salts like vivianite should not precipitate under oxidizing conditions (Bray et al., 1973) and ferric phosphate (strengite) should be soluble at the $\mathrm{pH}$ and concentrations involved (Stumm and Morgan, 1970). Phosphate sorption onto ferric hydroxides (Stumm and Morgan, 1970; Berner, 1973; Froelich et al., 1977) precipitated in the filters is a likely explanation. The failure to find distinct crystallographic evidence of phosphate minerals on aquarium gravel filters in other systems (Siddall, 1974) is not conclusive evidence against phosphate sorption or mixed calcium phosphates. Further studies should be done on phosphate geochemistry.

The alternate interpretation, a nitrogen excess, could only be explained by microbial fixation of atmospheric nitrogen. This possibility can be dismissed since microbial nitrogen fixation will not occur in an environment with a high nitrate concentration (Dicker and Smith, 1980) and the recirculating system always contained more nitrate than $20 \mu$ moles $\mathrm{Nl}^{-1}$ (Table 1). Thus a phosphate loss is invoked.

With this in mind, the nitrate buildup rate is used with the Redfield ratio to calculate the organic loading of the recirculating system for the two monitoring periods. The daily buildup of nitrate $\left(N_{B}\right)$ or phosphate $\left(P_{B}\right)$ over the entire monitoring period can be calculated from the net buildup plus interval estimates of amount of nutrient lost with Equation 1:

$N_{B}$ or $P_{B}=\left[\left(\Delta n V_{s}\right)+\Sigma\left(n_{i} V_{i}+n_{2} V_{2}+\ldots+n_{l} V_{d}\right)\right] \div V_{s} t$

where $n_{1,2, i}=$ nitrate or phosphate concentration in recirculating system at time $1,2, \cdots i_{i} \Delta \mathrm{n}=$ concentra tion change over complete monitoring period; $V_{s}=$ volume of recirculating seawater system $(19,000 \mathrm{l})$; $V_{1,2, i}=$ volume of water transferred to recirculating system to replace losses at time $1,2, \cdots i ; t=$ time of monitoring period, 111 and $68 \mathrm{~d}$ for winter and summer respectively.

Solving Equation 1 for the winter period results in $N_{B}$ $=4.42 \mu$ moles $\mathrm{Nl}^{-1} \mathrm{~d}^{-1}$ and $P_{B}=0.16 \mu$ moles $P I^{-1} d^{-1}$ with similar summer results of $5.12 \mu$ moles $\mathrm{N}^{-1} \mathrm{~d}^{-1}$ and $0.16 \mu$ moles $\mathrm{Pl}^{-1} \mathrm{~d}^{-1}$. With the Redfield ratio, the expected phosphate buildup $\left(N_{B}+16\right)$ would give values for winter and summer respectively of 0.28 and $0.32 \mu$ moles $\mathrm{Pl}^{-1} \mathrm{~d}^{-1}$. Again using the Redfield ratio, the nitrate buildup can be converted to organic carbon utilization (organic loading, $C_{L}$ ) by Equation 2:

$$
C_{L}=N_{B}(106 / 16)
$$

the results are 29 and $34 \mu$ moles $\mathrm{C}^{-1} \mathrm{~d}^{-1}$ respectively for winter and summer.

This approach for estimating organic loading is novel and perhaps the best way to determine an otherwise unquantifiable input. Sources of organic loading include animal excretion, degradation of molts and dead animals, and unused food swept through the recirculating system. These inputs normally, and definitely in this case, are not possible to measure directly. Since this is a contained ecosystem, the organic loading should be considered an input of reduced carbon and to have a role similar to primary production in the natural environment. Our recirculating system would thus have an organic input considerably higher than a rich coastal value of $0.8-4.2 \mu$ moles $\mathrm{Cl}^{-1} \mathrm{~d}^{-1}$ (Malone, 1977) and equivalent to a productive estuarine one of 8 to $42 \mu$ moles $\mathrm{Cl}^{-1} \mathrm{~d}^{-1}$ (Flemer, 1970).

\section{Nutrient Regeneration Rates}

In the recirculating seawater system, we can be fairly certain of our estimates of rates since we are working with an essentially closed, controlled system and since almost all forms of nitrogen and phosphorus have been measured. In natural systems, estimates of rates are made with much less certainty. However, the rates from this study can be compared to others from various types of research. For the comparison, results of published works will be used with some calculations to obtain estimates of phosphate regeneration and estimates will be listed for either closed systems or open waters in Table 2. Phosphate is used since some of the studies cited did not measure all forms of nitrogen. When nitrogen was measured, values are converted to phosphate using the Redfield ratio. It must be acknowledged from the start that microbial nutrient regeneration rates are dependent primarily upon substrate 
Table 2. Estimates of nutrient regeneration kinetics. All rates listed as phosphate buildup, although taken from various different actual measurements

\begin{tabular}{|c|c|c|c|}
\hline Study system & Measurement & Source & $P_{\mathrm{B}}\left(\mu\right.$ moles $\left.\mathrm{P}^{-1} \mathrm{~d}^{-1}\right)$ \\
\hline \multicolumn{4}{|l|}{ Closed system: } \\
\hline Bottle experiment & $\mathrm{PO}_{4}^{-3}$ buildup & Cooper (1936) & 0.02 \\
\hline Bottle experiment & $\mathrm{NO}_{3}^{-}$buildup & Von Brand et al. (1937) & $0.03-0.14$ \\
\hline Bottle experiment & $\mathrm{NH}_{4}^{+}$buildup & Von Brand et al (1937) & $0.05-0.18$ \\
\hline Bottle experiment & $\mathrm{PO}_{4}^{-3}$ buildup & Grill and Richards (1964) & 0.02 \\
\hline Bell jar & $\mathrm{NH}_{4}{ }^{+}$buildup & Rowe et al (1975) & 1.0 \\
\hline Bell jar & $\mathrm{PO}_{4}^{-3}$ buildup & Nixon et al. (1976a) & $1.1-10.9$ \\
\hline CEPEX bags & $\mathrm{NH}_{4}{ }^{+}$isotope dilution & Harrison $(1978)$ & $0.04-0.08$ \\
\hline Aquarium system & $\mathrm{NO}_{3}^{-}$buildup & This study & $0.28-0.32$ \\
\hline \multicolumn{4}{|l|}{ Open Waters: } \\
\hline B. C. coastal waters & $\mathrm{NH}_{4}{ }^{+}$isotope dilution & Harrison (1978) & $0.04-0.08$ \\
\hline Cal coastal waters & $\mathrm{NH}_{4}{ }^{+}$isotope dilution & Harrison (1978) & $0.001-0.01$ \\
\hline Cal. coastal waters & $\mathrm{NO}_{3}^{-}$uptake & Eppley et al. (1979) & $0.003-0.04$ \\
\hline Mex. coastal waters & $\mathrm{NO}_{3}^{-}$uptake & King and Devol (1979) & $0.002-0.04$ \\
\hline N. J. coastal waters & $\mathrm{PO}_{4}^{-3}$ buildup & Sharp and Church (1981) & 0.004 \\
\hline N. Y. Bight coastal waters & $\mathrm{PO}_{4}^{-3}$ buildup & Sharp (1982) & $0.01-0.02$ \\
\hline
\end{tabular}

availability rather than some inherent physiological capability of the ambient bacterial population. However, since nutrient availability is the primary ecological concern, experiments with realistic conditions should provide valuable information on rates.

Probably the first laboratory study of nutrient regeneration was that of Cooper (1936). He collected plankton with fine nets, placed it in bottles of seawater, and monitored orthophosphate over time. In the classic nitrogen regeneration experiments of von Brand et al. (1973), they displayed the progression through the nitrogen redox states from ammonium to nitrate. We calculate regeneration rates from their nitrate data converted with the Redfield ratio and similarly from their ammonium data. Both nitrogen and phosphorus were measured in the bottle experiment of Grill and Richards (1964). They reported an N/P regeneration rate (after an initial phosphate burst) of 16/1. However, they did not find oxidation to nitrate even after over a year. The initial phosphate liberation, presumably from autolysis, has been reported elsewhere (Hoffman, 1956; Golterman, 1964); we have also found ammonium rather than nitrate buildup in a similar plankton-decomposition experiment (Sharp and Gustafson, unpubl.).

In the above-mentioned 3 studies, concentrated plankton was decomposed in the dark by bacteria over a relatively long period of time. It is difficult to extrapolate such studies to the natural environment, so they probably are more valuable in a qualitative sense rather than for natural rates. Short-term nutrient buildup experiments as in 'bell jar' studies might be more realistic. In these, a box is placed over the sediment and short-term (several hours) chemical changes within the box are interpreted as due to benthic regeneration. Usually, these changes are expressed as fluxes for the enclosed sediment area, and assuming steady state conditions, the flux is interpreted as a regeneration rate. Two bell jar studies are included in Table 2 with calculations to get regeneration rates within the enclosed boxes. Rowe et al. (1975) include data from a bell jar used in Buzzard's Bay Massachusetts. From the volume and bottom surface area listed for their box, the height can be determined. Then, the recorded areal hourly flux, divided by the box height and multiplied by 24 , should give a daily nutrient regeneration rate for the box over the sediment. A similar appraach was used for bell jar data (Nixon et al., 1976a) from Narragansett Bay.

A totally different approach to nutrient regeneration measurements has been taken by Harrison (1978). He used an isotope dilution ${ }^{15} \mathrm{~N}$-ammonium uptake assay to estimate ammonium regeneration in enclosed seawater CEPEX bags in British Columbia coastal waters.

These closed system estimates and the values of the present study are given in Table 2. Although a seemingly large range of values are listed, a narrower range (0.02-0.32 $\mu$ moles $\left.\mathrm{P}^{-1} \mathrm{~d}^{-1}\right)$ is found if the benthic bell jar studies are excluded. The ball jar studies might be suspect because of the possibility of disturbing the bottom when placing them. All of these closed system studies suffer the artificiality of the concentrated organic matter being enclosed, preventing dispersal of the regenerated nutrients. The present recirculating seawater system study is different because it was not completely closed due to replacement of some of the water (an average of 3 to $5 \%$ daily) and it had a constant input of organic matter over time rather than a 
single one at the beginning. It is artificial in that it is a finite constrained system and the organic input was not directly from primary productivity. Our system gives nitrogen regeneration as nitrate, as in open aerobic environments, while the bottle experiments and bell jar studies primarily give ammonium production. The reason in the case of the bell jars is that the benthic fluxes reflect anaerobic nutrient regeneration. The bottle experiments of Grill and Richards (1964) and von Brand et al. (1937, 1939, 1940, 1941, 1942) give very slow or no nitrate production because ammonium production is much more rapid than nitrification and these systems were probably not extensively aerated. Estimates of nutrient regeneration in open aerobic environments have been made or can be made by simple recalculations.

In the work of Harrison (1978) mentioned above, the estimates of ammonium regeneration are fairly shortterm (24 h incubations) and the CEPEX bags contained natural populations. Thus the range of rates listed could be considered as representing open waters and are listed as such in Table 2. Harrison (1978) made similar estimates in southern California coastal waters and these values are also listed. Another way of estimating nutrient regeneration is to consider open water nitrate uptake to be controlled by, and hence equal to, subsurface microbial nitrate regeneration (Eppley et al., 1979; King and Devol, 1979). This is a slight extrapolation of the intent of these authors who were using an areal flux to calculate advection, but it is justified since steady state is assumed. In the study of Eppley et al. in southern California coastal waters, volume regeneration rates can be recalculated from listed areal fluxes by using Equation 3:

$$
d N / d t=\mathrm{e}_{\mathrm{NO}_{3}} \div Z_{n}
$$

where $d N / d t=\mu \mathrm{g}$ at $\mathrm{Nl}^{-1} \mathrm{~d}^{-1} ; \varrho_{\mathrm{NO}_{3}}=$ listed flux of $\mathrm{mg}$ at $\mathrm{N} \mathrm{m}^{-2} \mathrm{~d}^{-1} ; Z_{n}=$ depth of surface mixed layer. Using ranges of values they give for $\mathrm{eNO}_{3}$ and $Z_{n}$ Equation 3 is solved. Sharp and Church (1981) have estimated phosphate buildup in seasonally stratified bottom waters over a several month and hundred kilometer lateral scale. In a similar fashion, phosphate regeneration for New York Bight waters was estimated (Sharp, 1982).

All of the above estimates are given in Table 2 . If the types of environments are considered, the data can be arranged into 3 groups. Near oceanic environments could be considered to have regeneration less than $0.01 \mu$ moles $\mathrm{P} \mathrm{l}^{-1} \mathrm{~d}^{-1}$; this would include the lower values for California, Mexico, and New Jersey coastal waters. An intermediate group of richer coastal waters (0.01-0.04 $\mu$ moles $\mathrm{P}^{-1} \mathrm{~d}^{-1}$ ) would include the higher values for those same waters plus the New York Bight waters. Essentially estuarine waters $(>0.04 \mu$ moles
$\mathrm{P}^{-1} \mathrm{~d}^{-1}$ ) would include the British Columbia values and the present seawater system study. Thus the present study can be viewed as giving values comparable to extremely rich natural waters and can be considered to span between closed systems and open waters in experimental design.

\section{Nitrogen and Phosphorus Partitioning}

In the Redfield model, N/P ratios were considered for nitrate and phosphate. An abundance of good data for organic nitrogen and phosphorus have not been available previously for comparison to inorganic forms. Butler et al. (1979) have considered an 11 y data set from the English Channel with organic as well as inorganic measurements. With total dissolved nitrogen (nitrate, ammonium, organic nitrogen) and total dissolved phosphorus (phosphate plus organic phosphorus), they found an average ratio of about 20/1. Their $\mathrm{NO}_{3}{ }^{-} /$ $\mathrm{PO}_{4}{ }^{-3}$ ratio was generally lower than the Redfield ratio (varied seasonally from 3 to 13), but if $\mathrm{NH}_{4}{ }^{+}$is added to the $\mathrm{NO}_{3}{ }^{-}$, the yearly average ratio of dissolved inorganic nitrogen (DIN) to $\mathrm{PO}_{4}^{-3}$ is $13 / 1$. This shows that in surface coastal ocean waters with inorganic N/P near the Redfield ratio, the addition of dissolved organic forms gives an N/P which is appreciably higher. This observation is consistent with the well known phenomenon of organic $P$ being more labile than organic $N$.

Similar analysis can be made of data from this study using summer values from the stored system (Table 1). These samples represent surface coastal ocean waters collected in the summer. The average $\mathrm{DIN} / \mathrm{PO}_{4}{ }^{-3}$ is $17 /$ 1. Adding the organic nitrogen and phosphorus, the average total dissolved nitrogen (TDN) to total dissolved phosphorus (TDP) is $32 / 1$. As discussed above, the $\mathrm{N} / \mathrm{P}$ in the recirculating system increases above the Redfield ratio. If average values are taken from Table 1, the DIN/PO ${ }_{4}^{-3}$ is $26 / 1$ and the TDN/TDP is 35/ 1. This clearly shows an N/P for dissolved inorganic ions above the Redfield ratio, but again shows an increase in the ratio when dissolved organic components are added. In all three cases, the increase in the ratio is due to there being disproportionately more dissolved organic nitrogen in the water than dissolved organic phosphorues. Indeed, the dissolved organic phosphorus content in these three cases appears rather low and invariable with an average value of $0.23 \mu \mathrm{g}$ at $\mathrm{Pl}^{-1}$ for the English Channel (Butler et al., 1979), an average value for our coastal water of $0.28 \mu \mathrm{g}$ at $\mathrm{P}^{-1}$ and for our recirculating system of $0.23 \mu \mathrm{g}$ at $\mathrm{Pl}^{-1}$. Recent data from the Delaware Bay (Sharp et al., 1982) also shows a small range and low values for dissolved organic phosphorus when compared to dissolved organic nitrogen. 
In the study of Butler et al. (1979), mention is made of particulate nitrogen for the same sample area in the summer, of $20-60 \mu \mathrm{g} \mathrm{N}{ }^{-1}$. If a middle value is taken and converted to the molar equivalent, this gives a particulate nitrogen of $2.86 \mu \mathrm{g}$ at $\mathrm{N}^{-1}$. Adding it to the TDN yields total nitrogen (TN) and the various forms of nitrogen can be evaluated in terms of the TN. The dissolved inorganic nitrogen thus makes up $24 \%$ of the TN with the majority being in the dissolved and particulate organic fractions. Similarly in our stored system values, only $35 \%$ of the TN is DIN. Nitrogen partitioning can also be calculated for New England coastal waters by using tidal exchange marsh input data from Valiela and Teal (1979). In this case, the majority of the inorganic nitrogen is as ammonium rather than nitrate, but the DIN only makes up $12 \%$ of the TN. The dissolved organic nitrogen fraction is fairly similar for these three environments with values of $54 \%$ for the English Channel waters (Butler et al., 1979), $60 \%$ for middle Atlantic coastal waters (this study), and $62 \%$ for New England coastal waters (Valiela and Teal, 1979).

Further studies into partitioning of carbon, nitrogen, and phosphorus in natural waters will aid our understanding of biochemical cycling. The present seawater system study and recently published works show that the $\mathrm{N} / \mathrm{P}$ of total dissolved matter is probably consistently above the Redfield ratio due to a comparative scarcity of dissolved organic phosphorus and that dissolved organic nitrogen is the dominant form of total nitrogen (excluding dissolved $\mathrm{N}_{2}$ ) in surface coastal waters in the summer.

Acknowledgements. This research was partially supported by NSF grant OCE76-82571 and by funds from the College of Marine Studies. We thank Lucia Solorzano for valuable aid and advice on the analyses; Lester D. Fitler for design information on the seawater system; and $T M$. Church, $T R$. Fisher, C. E. Epifanio, J. Wu, and C. J. Lord for comments on an earlier version of the manuscript.

\section{LITERATURE CITED}

Adams, D. D. (1974). A laboratory model for plankton decomposition in anaerobic and aerobic seawater. Inst. Oceanography, Old Dominion University, Tech. Rep. 17: $1-228$

Atkinson, L. P., Richards, F. A. (1967). The occurrence and distribution of methane in the marine environment. Deep Sea Res. 14: 673-684

Atlas, E., Pytkowicz, R. M. (1977). Solubility behavior of apatites in seawater. Limnol. Oceanogr. 22: 290-300

Barber, R. T., Dugdale, R. C., Mac Isaac, J. J., Smith, R. L. (1971). Variations in phytoplankton growth associated with the source and conditioning of upwelling water. Invest. Pesq. 35: 171-193

Berner, R. A. (1973). Phosphate removal from seawater by adsorption on volcanogenic ferric oxides. Earth Planet. Sci. Lett. 18: 77-86
Bray, J. T., Bricker, O. P., Troup, B. N. (1973). Phosphate in interstitial waters of anoxic sediments: oxidation effects during sampling procedure. Science, N.Y. 180: 1362-1364

Butler, E. I., Knox, S., Liddicoat, M. I. (1979). The relationship between inorganic and organic nutrients in seawater. J. mar biol. Ass. U.K. 59: 239-250

Cline, J. D., Richards, F. A. (1972). Oxygen deficient conditions and nitrate reduction in the eastern tropical North Pacific Ocean. Limnol. Oceanogr. 17: 885-900

Cooper, L. H. N. (1935). The rate of liberation of phosphate in seawater by the breakdown of plankton organisms. J. mar. biol. Ass. U.K. 20: 197-200

Dicker, H. J., Smith, D. W. (1980). Physiological ecology of acetylene reduction (nitrogen fixation) in a Delaware salt marsh. Microbial Ecol. 6: 161-171

Eppley, R. W., Renger, E. H., Harrison, W. G. (1979). Nitrate and phytoplankton production in southern California coastal waters. Limnol. Oceanogr. 24: 483-494

Flemer, D. A. (1970). Primary production in the Chesapeake Bay. Chesapeake Sci. 11: 117-129

Froelich, P. N., Bender, M. L., Heath, G. R. (1977). Phosphorus accumulation rates in metalliferous sediments on the East Pacific Rise. Earth Planet. Sci. Lett. 34: 351-359

Golterman, H. L. (1964). Mineralization of algae under sterile conditions or by bacterial breakdown. Int. Ver. Theor. Angew. Limnol. Verh 15: 544-548

Grill, E. V., Richards, F. A. (1964). Nutrient regeneration from phytoplankton decomposing in seawater. J. mar. Res. 22: 51-69

Harrison, W. G. (1978). Experimental measurements of nitrogen remineralization in coastal waters. Limnol. Oceanogr. 23: $684-694$

Hoffman, K. (1956). Untersuchungen über die Remineralisation des Phosphors im Plankton. Kieler Meeresforsch. 12: 25-36

Kaplan, W., Valiela, I., Teal, J. M. (1979). Denitrification in a salt marsh ecosystem. Limnol. Oceanogr. 24; 726-734

King, F. D., Devol, A. H. (1979). Estimates of vertical eddy diffusion through the thermocline from phytoplankton nitrate uptake rates in the mixed layer of the eastern tropical Pacific. Limnol. Oceanogr. 24: 645-651

Koroleff, F. (1976). Total and organic nitrogen. In: Grasshoff, K. (ed.) Methods of seawater analysis. Verlag Chemie, New York, pp. 167-181

Liddicoat, M. I., Tibbitts, S., Butler, E. I. (1975). The determination of ammonia in seawater. Limnol. Oceanogr. 20 : $131-132$

Malone, T. C. (1977). Light-saturated photosynthesis by phytoplankton size-fractions in the New York Bight, USA. Mar. Biol. 42: 281-292

McCaffrey, R. J., Myers, A. C., Davey, E., Morrison, G., Bender, M., Luedtke, N., Cullen, D., Froelich, P., Klinkhammer, G. (1980). The relation between pore water chemistry and benthic fluxes of nutrients and manganese in Narragansett Bay, Rhode Island. Limnol. Oceanogr. 25: 31-44

Menzel, D. W. (1977). Summary of experimental results: controlled ecosystem pollution experiment. Bull. mar. Sci. 27 142-145

Menzel, D. W., Vaccaro, R. F. (1964). The measurement of dissolved organic and particulate carbon in seawater. Limnol. Oceanogr. 9: 138-142

Morse, J. W., Cook, N. (1978). The distribution and form of phosphorus in North Atlantic Ocean deep-sea and continental slope sediments. Limnol. Oceanogr. 23: 825-830

Nixon, S. W., Oviatt, C. A., Hale, S. S. (1976a). Nitrogen regeneration and metabolism of coastal marine bottom communities. In: Anderson, J. M., Macfadyen, A. (eds.) 
The role of terrestrial and aquatic organisms in decomposition processes. Blackwell, Oxford, pp. 269-283

Nixon, S. W., Oviatt, C. A., Gruber, J., Lee, V (1976b). Diel metabolism and nutrient dynamics in a salt marsh embayment. Ecology 57: 740-750

Pilson, M. E. Q. (1979). The MERL Ecosystems, University of Rhode Island, Kingston

Redfield, A. C., Ketchum, B. H., Richards, F. A. (1963). The influence of organisms on the composition of seawater. In: Hill, M. N. (ed.) The sea, Vol. II. Interscience, New York, pp. $26-27$

Richards, F. A. (1965). Anoxic basins and fjords. In: Riley, J. P., Skirrow, G. (eds.) Chemical oceanography, 1st. ed. Vol. 1. Academic Press, New York, pp. 611-645

Richards, F. A., Anderson, J. J., Cline, J. D. (1971). Chemical and physical observations in Golfo Dulce, an anoxic basin on the Pacific coast of Costa Rica. Limnol. Oceanogr 16: 43-50

Rowe, G., Clifford, C. H., Smith, K. L., Jr., Hamilton, P. L. (1975). Benthic nutrient regeneration and its coupling to primary productivity in coastal waters. Nature, Lond. 255: $215-217$

Sharp, J. H. (1973). Total organic carbon in seawater. Comparison of measurements using persulfate oxidation and high temperature combustion. Mar. Chem. 1: 211-229

Sharp, J. H. (1974). Improved analysis for 'particulate' organic carbon and nitrogen from seawater. Limnol. Oceanogr 19 : 984-989

Sharp, J. H. (1982). In situ phosphate regeneration in Middle Atlantic coastal waters. In: Mayer, G. F. (ed.) Ecological stress and the New York Bight: science and management. Estuarine Research Federation (in press)

Sharp, J. H., Church, T. M. (1981). Biochemical modeling in Middle Atlantic Coastal waters. Limnol. Oceanogr. 26: 843-854

Sharp, J. H., Culberson, C. H., Church, T. M. (1982). The chemistry of the Delaware Estuary. General considerations. (Submitted)

Siddall, S. E. (1974). Studies of closed marine culture systems. Progve Fish Cult. 36: 8-15

Solorzano, L. (1969). Determination of ammonia in natural waters by the phenolhypochlorite method. Limnol, Oceanogr. 14: 799-801
Solorzano, L., Sharp, J. H. (1980a). Determination of total dissolved phosphorus and particulate phosphorus in natural waters. Limnol. Oceanogr. 25: 756-760

Solorzano, L., Sharp, J. H. (1980b). Determination of total dissolved nitrogen in natural waters. Limnol. Oceanogr 25: 753-756

Strickland, J. D. H., Parsons, T R. (1972). A practical handbook of seawater analysis, 2nd ed. Fish. Res. Bd Can. Bull. 167: $1-310$

Stumm, W., Morgan, J. J. (1970). Aquatic chemistry, John Wiley \& Sons, New York

Valiela, I., Teal, J. M. (1979). The nitrogen budget of a salt marsh ecosystem. Nature, Lond. 280: 652-656

von Brand, T., Rakestraw, N. W. (1940). The decomposition and regeneration of nitrogenous organic matter in seawater. III. The influence of temperature and condition of the water. Biol. Bull. mar. biol. Lab., Woods Hole 79: 231-236

von Brand, T., Rakestraw, N. W. (1941). Decomposition and regeneration of nitrogenous organic matter in seawater. IV. Interrelationships of various stages; influence of concentration and nature of particulate matter. Biol. Bull. mar. biol. Lab, Woods Hole 81: 63-69

von Brand, T., Rakestraw, N. W., Renn, C. E. (1937). The experimental decomposition and regeneration of nitrogenous organic matter in seawater. Biol. Bull. mar. biol. Lab., Woods Hole 72: 165-175

von Brand, T., Rakestraw, N. W., Renn, C. E. (1939). Further experiments on the decomposition and regeneration of nitrogenous organic matter in seawater. Biol. Bull. mar biol. Lab., Woods Hole 77: 285-296

von Brand, T., Rakestraw, N. W., Zabor, J. W (1942). Decomposition and regeneration of nitrogenous organic matter in seawater. V. Factors influencing the length of the cycle; observations upon gaseous and dissolved organic nitrogen. Biol. Bull. mar. biol. Lab., Woods Hole 83: 273--282

Webb, K. L., D'Elia, C. F. (1980). Nutrient and oxygen redistribution during a spring neap tidal cycle in a temperate estuary. Science, N.Y. 207: 983-985

Weibe, P. H., Hulburt, E. M., Carpenter, E. J., Jahn, A. E., Knapp, G. P., Boyd, S. H., Ortner, P. B., Cox, J. L. (1976). Gulf stream cold rings: large scale interaction sites for open ocean plankton communities. Deep Sea Res. 23: $695-710$ 